\title{
POŠTA
}

TELEKOMUNIKÁCIE A

ELEKTRONICKÝ OBCHOD

\section{VPLYV NÁKLADOV POISŤOVNE NA BEŽNÚ SPLÁTKU BRUTTO POISTNÉHO}

\author{
Lucia Švábová ${ }^{1}$
}

\section{Základné pojmy}

Poistenie zabezpečuje právo na vyplatenie poistnej sumy $\mathrm{v}$ dohodnutej výške $\mathrm{v}$ prípade nastatia poistnej udalosti $\mathrm{v}$ priebehu trvania poistenia. Touto poistnou udalost'ou sa rozumie napr. úmrtie v priebehu trvania poistenia alebo dožitie sa určitého veku. Poistná udalost' má charakter náhodnej udalosti, pri poistení osôb sa poist’ujú náhodné udalosti súvisiace so životom, úmrtím a zdravím.

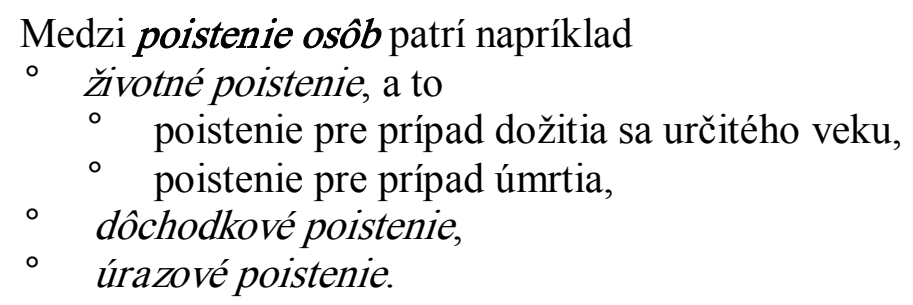

Výpočet poistného sa riadi nasledujúcimi dvoma princípmi:

1. Princíp fiktívneho súboru

Počet osôb uzatvárajúcich vo veku $x$ ten istý typ poistnej zmluvy je $1_{x}$, pričom predpokladáme, že všetci sa narodili 1. januára a zomreli 31. decembra.

2. Princíp ekvivalencie

Pri uzatváraní súboru poistných zmlúv toho istého typu musia byt'v rámci súboru všetky príjmy poistovne (plynúce z poistného) v rovnováhe s jej výda vkami (očakávané poistné plnenia), ked' príjmy a výda vky sa diskontujú k spoločnej časovej základni (k dátumu uzatvorenia poistnej zmluvy).

Úmrtnostné tabul'ky poskytujú základné informácie o úmrtnostnom správaní sa uzavretej stacionárnej populácie, pričom sa predpokladá, že nedochádza k migrácii obyvatel'stva, v čase sa nemení vel'kost' a vekové zloženie populácie. Úmrtnostná tabul'ka uvádza počty osôb fiktívneho súboru, ktoré sa dožili veku 15 až 85 rokov, prípadne ktoré zomreli v týchto vekoch a tiež ročnú mieru úmrtnosti a ročnú mieru dožitia, ktoré sú odvodené z počtu zomrelých a počtu žijúcich osôb v jednotlivých vekoch.

Komutačné čísla sa počítajú z úmrtnostných tabuliek a d’alej sa využívajú pri výpočte poistných súm v poistení osôb. Medzi komutačné čísla počtu žijúcich patria

\footnotetext{
${ }^{1}$ RNDr. Lucia Švábová, Katedra kvantitatívnych metód a hospodárskej informatiky, Fakulta prevádzky a ekonomiky dopravy a spojov, Žilinská univerzita, Univerzitná 1, 01026 Žilina, tel.: 5133140, e-mail: lucia.svabova@fpedas.uniza.sk
} 
- $D_{x}=I_{x} \cdot v^{x}$, kde člen $v=\frac{1}{1+i}$ sa nazýva odúročitel' (diskontný faktor), pričom $i$ je poistno - technická úroková miera. Toto komutačné číslo reprezentuje počet žijúcich vo veku $x$ odúročený (diskontovaný) $\mathrm{k}$ ich dátumu narodenia.

$$
\begin{aligned}
& \circ N_{x}=D_{x}+D_{x+1}+\ldots+D_{x+\omega}=\sum_{k=0}^{\omega-x} D_{x+k} \\
& \circ S_{x}=N_{x}+N_{x+1}+\ldots N_{x+\omega}=\sum_{k=0}^{\omega-x} N_{x+k}
\end{aligned}
$$

Medzi komutačné čísla počtu zomrelých patria

○ $C_{x}=d_{x} \cdot v^{x+1}$, toto komutačné číslo reprezentuje počet osôb zomrelých vo veku $X$ odúročený $\mathrm{k}$ dátumu ich narodenia.

$$
\begin{aligned}
& M_{x}=C_{x}+C_{x+1}+\ldots+C_{x+\omega}=\sum_{k=0}^{\omega-x} C_{X+k} \\
& \circ R_{x}=M_{x}+M_{x+1}+\ldots+M_{X+\omega}=\sum_{k=0}^{\omega-x} M_{X+k}
\end{aligned}
$$

Použitie komutačných čísel v poistnej matematike zjednodušuje všetky poistno - matematické výpočty.

Jednorázové netto poistné je poistné bez nákladov poist'ovne zaplatené pri uzatvorení poistnej zmluvy. V praxi sa väčšinou poistenie neplatí jednorázovo, ale v pravidelných, napr. ročných alebo štvrt'ročných splátkach. Prvé poistné sa zaplatí po podpise poistnej zmluvy, ide teda o predlehotné platenie a d'alšie splátky sa platia podl'a toho, ako je dohodnuté. Tieto jednotlivé splátky nazývame bežné netto poistné.

Ak vezmeme do úvahy náklady, ktoré poist’ovňa vynakladá pri uzatvorení a vedení poistnej zmluvy a budeme sa zaoberat' poistným, ktoré zohl'adňuje aj tieto náklady poist'ovne, toto poistné nazývame brutto poistné.

Náklady, ktoré musíme zohl'adnit' pri výpočte brutto poistného sa delia na:

- Jednorázové počiatočné náklady - tieto sa označujú $\alpha$ a môžu byt' vo výške $3-5 \%$ z poistnej sumy. Ide o náklady, ktoré súvisia s uzatvorením poistnej zmluvy (propagácia, provízia dealerovi atd’.). Započítavajú sa do poistného.

Ak je poistné platené bežne, musia sa jednorázové začiatočné náklady rozdelit' do jednotlivých splátok poistného.

- Správne náklady - označujeme $\beta$, môžu byt' vo výške $2-8 \%$ z poistnej sumy. V týchto nákladoch sú započítané dane, nájomné, náklady na prevádzku poist'ovne. Rozdel'ujú sa na

- správne náklady $\beta_{1}$, ktoré sa vynakladajú počas celej poistnej doby,

- správne náklady $\beta_{2}$, ktoré sa vynakladajú len počas doby platenia poistného.

Ak doba platenia poistného je kratšia ako doba trvania poistenia, tak bude $\beta=\beta_{1}+\beta_{2}$. Ak doba platenia poistného je rovnaká ako doba trvania poistenia, tak správne náklady $\beta$ sa nerozkladajú na dve zložky.

Ak je poistné platené jednorázovo, tak správne náklady $\beta_{2}$ sú nulové, berieme do úvahy len náklady $\beta_{1}$.

- Inkasné náklady - označujú sa $\gamma$ a sú to náklady, ktoré súvisia s bežným platením poistného. Môžu byt' vo výške $1-10 \%$ z brutto poistného. Pri poistnom platenom jednorázovo sa inkasné náklady nezapočítavajú. 


\section{Zmiešané poistenie}

Majme $x$ - ročnú osobu, ktorá sa poistí tak, že ak zomrie do veku $x+n$ rokov, bude jej dedičom (oprávneným osobám) vyplatená dohodnutá poistná suma (pre prípad úmrtia) a ak sa dožije veku $x+n$, bude jej vyplatená dohodnutá poistná suma (pre prípad dožitia).

Označíme $\left.A_{x, n}\right]^{-}$jednorázové netto poistné pre prípad zmiešaného poistenia zloženého $\mathrm{z}$ dočasného poistenia na úmrtie a $\mathrm{z}$ poistenia na dožitie.

Výška jednorázového netto poistného pre takýto typ poistnej zmluvy s použitím komutačných čísel sa vypočíta podl'a nasledujúceho vzorca

$$
A_{x, n]}=\frac{M_{x}-M_{x+n}}{D_{x}}+\frac{D_{x+n}}{D_{x}} .
$$

Bežne platené netto poistné (platené počas celej doby trvania poistnej zmluvy) je dané

$$
{ }_{n} P\left(A_{x, n]}\right)=\frac{M_{x}-M_{x+n}+D_{x+n}}{N_{x}-N_{x+n}} .
$$

A nakoniec vzorec pre výpočet bežne plateného brutto poistného je nasledujúci

$$
{ }_{n} B_{x}=\frac{1}{1-\gamma} \cdot\left({ }_{n} P\left(A_{x, n]}\right)+\frac{\alpha}{\ddot{a}_{x, n]}}+\beta\right) .
$$

Po dosadení komutačných čísel

$$
{ }_{n} B_{x}=\frac{1}{1-\gamma} \cdot\left(\frac{M_{x}-M_{x+n}+D_{x+n}}{N_{x}-N_{x+n}}+\frac{D_{x}}{N_{x}-N_{x+n}} \cdot \alpha+\beta\right) .
$$

Týmto modelom sa budeme d'alej zaoberat' a budeme skúmat' vplyv jednotlivých jeho parametrov na konečnú výšku splátky brutto poistného.

\section{Analýza modelu}

Pre jednoduchost' zvolíme jednotný vstupný vek osoby $x=25$ rokov. Výška poistnej sumy bude 1000000 Sk na úmrtie aj na dožitie. Doba trvania poistenia bude $n=35$ rokov. (Vplyv poistnej doby na výšku splátky nebudeme skúmat', nakol'ko je zrejmé, že pri rovnakej poistnej sume a dlhšom čase splácania bude splátka brutto poistného nižšia. Podobne je to s výškou poistnej sumy).

Náklady poist'ovne $\alpha, \beta$ a $\gamma$ zvolíme spočiatku v minimálnej výške a postupne budeme menit' výšku jednotlivých nákladov pri nezmenených ostatných parametroch poistenia. Nech teda na začiatok platí $\alpha=3 \%$

$$
\begin{aligned}
& \beta=2 \% \text { o } \\
& \gamma=1 \%
\end{aligned}
$$

\section{Vplyv parametra $\alpha$ (jednorázové počiatočné náklady)}

Ako už bolo spomenuté vyššie, náklady $\alpha$ súvisia s uzatvorením poistnej zmluvy a započítavajú sa do poistného. Ked’že v našom prípade ide o poistné platené bežne $n$ rokov, musia byt' zahrnuté do jednotlivých splátok poistného.

Výšku nákladov $\alpha$ sme postupne zvyšovali o desatinu až do $\alpha=5 \%$. V nasledujúcej tabul'ke sú uvedené výšky splátok bežného brutto poistného, ktoré sme takto dostali. 


\begin{tabular}{|c|c|c|c|c|c|c|c|c|c|c|c|}
\hline alfa & 0,03 & 0,031 & 0,032 & 0,033 & 0,034 & 0,035 & 0,036 & 0,037 & 0,038 & 0,039 & 0,04 \\
\hline poistné & 19692 & 19747 & 19802 & 19857 & 19912 & 19967 & 20021 & 20076 & 20131 & 20186 & 20241 \\
\hline alfa & 0,041 & 0,042 & 0,043 & 0,044 & 0,045 & 0,046 & 0,047 & 0,048 & 0,049 & 0,05 & \\
\hline poistné & 20296 & 20351 & 20406 & 20460 & 20515 & 20570 & 20625 & 20680 & 20735 & 20790 & \\
\hline
\end{tabular}

Tabul'ka 1 Výška splátky bežného brutto poistného s rôznymi nákladmi $\alpha$

Ako vidno z tabul'ky, v prípade, že si poist'ovňa určí počiatočné náklady vo výške $3 \%$, poistený bude platit' ročne brutto poistné vo výške $19692 \mathrm{Sk}$. Ak by sa poist'ovňa rozhodla stanovit' počiatočné náklady vo výške $5 \%$, poistený zaplatí ročné poistné 20790 Sk, čo predstavuje približne $6 \%$ nárast poistného. Za 35 rokov platenia poistného by rozdiel medzi týmito sumami bol vo výške 38430 Sk.

\section{Vplyv parametra $\beta$ (správne náklady)}

Rovnako ako aj v prípade nákladov $\alpha$, správne náklady $\beta$ sa tiež započítavajú do bežnej splátky poistného. Ked’že $\mathrm{v}$ našom prípade je doba trvania poistenia aj doba platenia poistného rovnaká, náklady $\beta$ sa nerozkladajú na dve zložky $\beta_{1}$ a $\beta_{2}$. Nasledujúca tabul'ka uvádza výšku splátky brutto poistného v závislosti od nákladov $\beta$ s krokom $0,5 \%$.

\begin{tabular}{|c|c|c|c|c|c|c|c|c|c|c|c|c|c|}
\hline $\begin{array}{c}\text { Beta } \\
{[\%]}\end{array}$ & 2 & 2,5 & 3 & 3,5 & 4 & 4,5 & 5 & 5,5 & 6 & 6,5 & 7 & 7,5 & 8 \\
\hline poistné & 19327 & 19832 & 20337 & 20842 & 21347 & 21852 & 22357 & 22862 & 23367 & 23873 & 24378 & 24883 & 25388 \\
\hline
\end{tabular}

Tabul'ka 2 Výška splátky brutto poistného s rôznymi nákladmi $\beta$

Ako vidno z tabul'ky, náklady $\beta$ majú vel'ký vplyv na výšku splátky poistného. Pri minimálnych nákladoch $\beta$ je poistné vo výške 19327 Sk ročne, pri maximálnych je to už $25388 \mathrm{Sk}$, čo predstavuje rozdiel $6061 \mathrm{Sk}$. V priebehu 35 rokov platenia poistného je rozdiel vo výške $212135 \mathrm{Sk}$.

\section{Vplyv parametra $\gamma$ (inkasné náklady)}

Inkasné náklady súvisia $\mathrm{s}$ bežným platením poistného a počítajú sa $\mathrm{z}$ brutto poistného vo výške $1-10 \%$. V tabul'ke 3 sú uvedené poistné sumy s rôznymi nákladmi $\gamma$.

\begin{tabular}{|l|c|c|c|c|c|c|c|c|c|c|}
\hline gamma & $\mathbf{0 , 0 1 0 0}$ & $\mathbf{0 , 0 1 5 0}$ & $\mathbf{0 , 0 2 0 0}$ & $\mathbf{0 , 0 2 5 0}$ & $\mathbf{0 , 0 3 0 0}$ & $\mathbf{0 , 0 3 5 0}$ & $\mathbf{0 , 0 4 0 0}$ & $\mathbf{0 , 0 4 5 0}$ & $\mathbf{0 , 0 5 0 0}$ & $\mathbf{0 , 0 5 5 0}$ \\
\hline poistné & 19039 & 19135 & 19233 & 19332 & 19431 & 19532 & 19634 & 19736 & 19840 & 19945 \\
\hline gamma & $\mathbf{0 , 0 6 0 0}$ & $\mathbf{0 , 0 6 5 0}$ & $\mathbf{0 , 0 7 0 0}$ & $\mathbf{0 , 0 7 5 0}$ & $\mathbf{0 , 0 8 0 0}$ & $\mathbf{0 , 0 8 5 0}$ & $\mathbf{0 , 0 9 0 0}$ & 0,0950 & $\mathbf{0 , 1 0 0 0}$ & \\
\hline poistné & 20051 & 20159 & 20267 & 20377 & 20487 & 20599 & 20712 & 20827 & 20943 & \\
\hline
\end{tabular}

Tabul'ka 3 Splátka brutto poistného s rôznymi nákladmi $\gamma$

V tomto prípade je rozdiel medzi minimálnou a maximálnou splátkou vo výške 1904 Sk, čo za 35 rokov platenia poistného predstavuje sumu $66640 \mathrm{Sk}$.

\section{Porovnanie nákladov}

Nasledujúci obrázok uvádza porovnanie splátok poistného v závislosti od výšky nákladov, pričom ostatné parametre poistenia ostávajú nezmenené. $Z$ obrázku je zrejmé aj to, čo sme zistili porovnaním jednotlivých splátok poistného a to, že náklady $\beta$ majú výrazne najväčší vplyv na výšku splátky. 


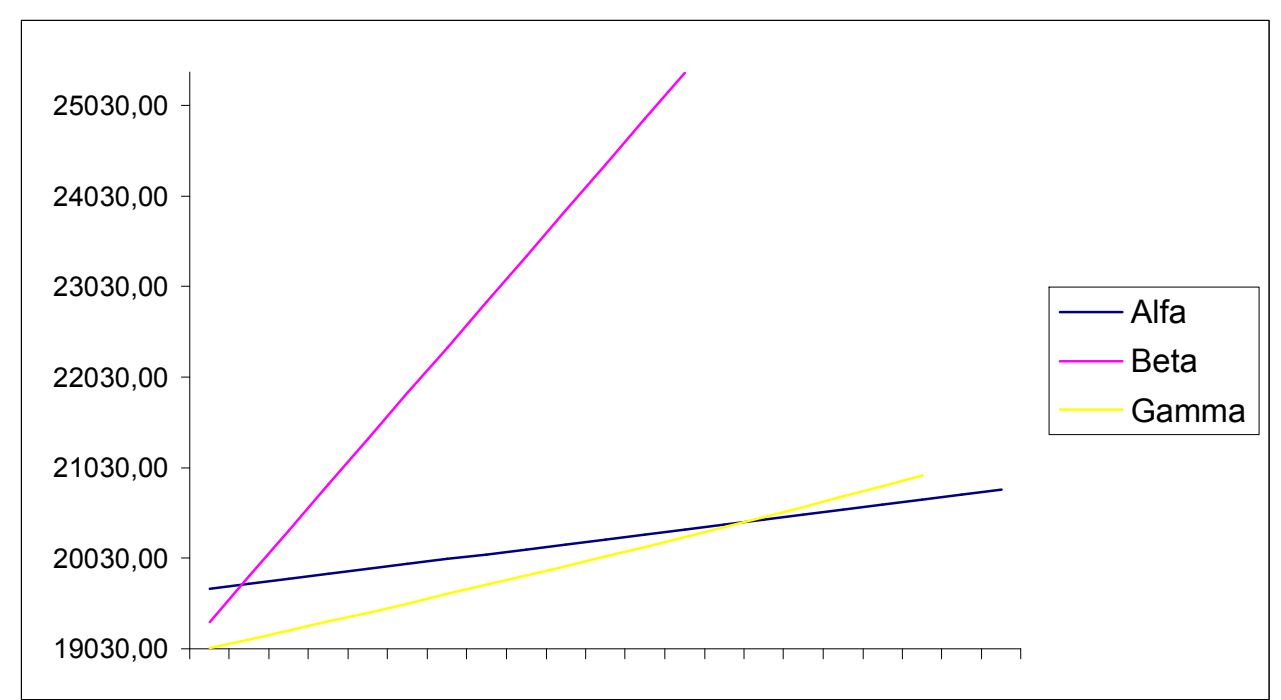

Obrázok 1 Porovnanie splátok brutto poistného v závislosti od rôznych nákladov poisto ovne

\section{Záver}

Stanovenie nákladov poist'ovne, ktoré bude táto využívat' pri výpočte splátok poistného pre svojich poistencov je stále aktuálnou otázkou poistných matematikov. Tieto náklady musia dostatočne pokryt' všetky výdavky, ktoré poist'ovňa vynakladá v súvislosti s uzatvorením a správou poistnej zmluvy. Z pohl'adu poistenej osoby predstavujú nemalú položku v splátke poistného, ktorú bude poistený platit' počas dohodnutej doby, ako sme mohli vidiet' na modelovom príklade uvedenom v tomto článku.

\section{Literatúra}

[1] ŠPIRKOVÁ, J. : Prednášky a cvičenia z predmetu Poistná matematika, odbor Matematická štatistika a finančná matematika, Fakulta prírodných vied UMB, 2003

[2] ŠPITALSKÝ, V. : Prednášky a cvičenia z predmetu Poistná matematika, odbor Matematická štatistika a finančná matematika, Fakulta prírodných vied UMB, 2004

[3] SEKEROVÁ, V, BILÍKOVÁ, M..: Poistná matematika, Vydavatel'stvo Ekonóm, Bratislava, 2005. 180 s. ISBN 80-225-2001-2. 